\title{
Whole-body calorimetry studies in adult men
}

\section{The effect of fat over-feeding on $24 \mathrm{~h}$ energy expenditure}

\author{
BY HELEN M. DALLOSSO* AND W. P. T. JAMES $\dagger$ \\ Medical Research Council Dunn Clinical Nutrition Centre, Addenbrooke's Hospital, \\ Trumpington Street, Cambridge CB2 lQU
}

(Received 10 August 1983 - Accepted 26 January 1984)

\begin{abstract}
1. Eight young men of normal weight were maintained for 1 week on a weight-maintenance diet followed by a 1-week period of over-feeding with extra fat designed to increase energy intake by $50 \%$. Two $36 \mathrm{~h}$ calorimetry sessions with low and high physical activities were included in each feeding period. Faecal and urine collections permitted checks on energy malabsorption and nitrogen excretion.

2. Over-feeding led to increases in body-weight, faecal energy and $\mathbf{N}$ excretion and in estimated $\mathbf{N}$ retention. Faecal energy outputs on the maintenance and over-feeding diets were 5 and $4.4 \%$ of the respective gross energy intakes.

3. Energy expenditure on fat over-feeding increased by $5.6 \%$ on the low-activity regimen and $6.4 \%$ on the high-activity regimen. This amounted, in terms of the extra energy intake, to 9 and $11 \%$ on the inactive and active schedules respectively. The increase affected day- and night-time rates of energy expenditure plus the basal metabolic rate. Individuals with a low percentage body fat showed the greatest response to over-feeding.

4. Nutrient-balance studies derived from calorimetry suggested that fat over-feeding led to substantial fat deposition with no evidence of sparing of carbohydrate oxidation. The theoretical cost of depositing dietary fat was exceeded, suggesting that regulatory thermogenic mechanisms may have been stimulated to a small extent.
\end{abstract}

The extent to which individuals adjust to a raised energy intake by increasing their level of energy expenditure is controversial. An appreciable capacity to dissipate energy would suggest one mechanism for weight stability and an inability to dispose of excess energy may then account for the development of obesity. The evidence for heat dissipation stems mainly from over-feeding studies where the weight gained has been less than predicted from the excess energy intake. Neumann (1902) demonstrated how he was able to maintain his body-weight within narrow limits despite increasing his daily energy intake from $7.4 \mathrm{MJ}$ to $10 \mathrm{MJ}$ over a period of 3 years. He introduced the term 'luxuskonsumption' to describe this wastage of energy. More recent work has supported this hypothesis. Miller \& Mumford (1967) have shown that a group of students on a low-protein diet could be over-fed by an extra $5.8 \mathrm{MJ} / \mathrm{d}$ with an average weight gain of only $1.1 \mathrm{~kg}$. This increase compares with an expected weight gain of approximately $5 \mathrm{~kg}$ if all the energy had been retained. A group over-fed to the same extent on a high-protein diet gained more weight but still less than the theoretical value. Sims and co-workers (Sims et al. 1973) in a series of studies, now known as the Vermont Prison Studies, demonstrated that thin young men could voluntarily over-eat under supervision about twice their usual intake for a number of months and yet show only a small gain in weight.

Unfortunately very few studies have actually measured the increase in energy expenditure during over-feeding, and most of these have only been able to look at the effects on basal metabolic rate (BMR) or resting metabolic rate (RMR) and the energy costs of certain activities. These studies have been reviewed by Garrow (1974). In the Miller \& Mumford

Present addresses: *Department of Physiology and Pharmacology, University of Nottingham Medical School, Queen's Medical Centre, Clifton Boulevard, Nottingham NG7 2UH. †Rowett Research Institute, Greenburn Road, Bucksburn, Aberdeen AB2 9SB. 
study (1967) there was no detectable change in BMR, but later studies by the Sims group (Danforth et al. 1979) did show an increase in BMR. Norgan \& Durnin (1980) demonstrated an increase in BMR when six men were over-fed for a period of 6 weeks but they attributed this to increases in body-weight. Studies which estimate values for $24 \mathrm{~h}$ energy expenditure in practice measure expenditure for short periods and then extrapolate with the use of activity diaries to a value for $24 \mathrm{~h}$. Only two studies have measured continuously for $24 \mathrm{~h}$ the effect of over-feeding on rates of energy expenditure. Apfelbaum et al. (1971) gave eight subjects a 'normal' diet plus a daily supplement of $6276 \mathrm{~kJ}$ for $15 \mathrm{~d}$. Oxygen consumption was measured continuously while the subject was restricted to bed for $24 \mathrm{~h}$. There was a mean increase in $24 \mathrm{~h} \mathrm{O}_{2}$ uptake of $11 \%$ and this was apparent throughout the day and night and during the measurement of BMR. Dauncey (1980) measured the effect of over-feeding a mixed diet high in fat for $24 \mathrm{~h}$ only, in four men and four women in a whole-body direct calorimeter. The mean level of over-feeding was $65 \%$ and there was a $10 \%$ increase in $24 \mathrm{~h}$ energy expenditure, and again this was present during the day and night and the next morning while the BMR was being measured.

One explanation for the low weight gains during over-feeding suggested by Miller et al. (1967) is that of a synergistic thermic effect of feeding and exercise. The Apfelbaum et al. (1971) study excluded exercise and in Dauncey's (1980) study the subjects performed only a small amount of activity. The present work was therefore conducted to look at the effects of over-feeding on $24 \mathrm{~h}$ energy expenditure and to identify any synergism between diet-induced thermogenesis and exercise. The subjects were over-fed for 1 week which made it possible to check faecal losses of energy and to make a preliminary assessment of the weight gained. The specific question of whether the thermic effect of feeding is enhanced during exercise will be discussed in the second paper (Dallosso \& James, 1984).

\section{METHODS}

\section{Subjects}

Eight male volunteers were studied and all were healthy non-smokers. The characteristics of the individual subjects are given in Table 1. The mean age was 22.9 (SD 2.0) years and all the subjects were within $10 \%$ of their ideal body-weight (Metropolitan Life Insurance Co., 1960). Each subject was studied continuously for a period of $14 \mathrm{~d}$ during which time he lived in the metabolic suite at the Dunn Clinical Nutrition Centre in Cambridge. This enabled him to eat only the diets and beverages prepared especially for him, to collect faeces and urine and to undergo the various experimental procedures. Within the constraints of the experimental design, the subject was free to continue his normal work and activities during the 2 weeks of the study. He was asked to refrain from any unusual extremes of physical activity and to maintain his normal lifestyle throughout the study.

\section{Experimental design}

A summary of the experimental timetable is given in Fig. 1. It consisted of two experimental periods of $7 \mathrm{~d}$ each (maintenance and over-feeding respectively). During the maintenance week the subject was given a level of energy intake sufficient to maintain his body-weight and during the over-feeding week this was increased by $50 \%$. During both experimental weeks each subject occupied the calorimeter for two separate $36 \mathrm{~h}$ periods, designated high exercise and low exercise. The subjects were always studied in pairs and the order of presentation of the different exercise programmes in the calorimeter was alternated for subsequent pairs of subjects, as shown in Table 1 . The various methods employed are described in detail in the following sections. The study received ethical approval from the Dunn Nutrition Unit's Ethical Committee. 
Table 1. Physical characteristics of subjects

\begin{tabular}{|c|c|c|c|c|c|c|c|c|c|}
\hline \multirow{2}{*}{$\begin{array}{c}\text { Subject } \\
\text { no. }\end{array}$} & \multirow{2}{*}{$\begin{array}{c}\text { Age } \\
\text { (years) }\end{array}$} & \multirow{2}{*}{$\begin{array}{l}\text { Height } \\
\text { (m) }\end{array}$} & \multirow{2}{*}{$\begin{array}{l}W^{*} \\
(\mathrm{~kg})\end{array}$} & \multicolumn{4}{|c|}{ Order of treatments } & \multicolumn{2}{|c|}{$\begin{array}{l}\text { Habitual energy } \\
\text { intake } \nmid(\mathrm{kJ} / \mathrm{d})\end{array}$} \\
\hline & & & & \multicolumn{2}{|c|}{ Maintenance } & \multicolumn{2}{|c|}{ Over-feeding } & \multirow{2}{*}{$\frac{\text { Mean }}{10485}$} & \multirow{2}{*}{$\frac{\mathrm{SD}}{1356}$} \\
\hline 1 & 22 & 1.681 & 63.9 & L & $\mathbf{H}$ & $\mathbf{H}$ & $\mathbf{L}$ & & \\
\hline 2 & 21 & 1.827 & $69 \cdot 5$ & $\mathrm{~L}$ & $\mathbf{H}$ & $\mathrm{H}$ & L & 13475 & 3409 \\
\hline 3 & 23 & 1.816 & $75 \cdot 6$ & $\mathbf{H}$ & $\mathbf{L}$ & $\mathbf{H}$ & $\mathbf{L}$ & 15463 & 2750 \\
\hline 4 & 23 & 1.855 & $69 \cdot 2$ & $\mathbf{H}$ & $\mathrm{L}$ & $\mathbf{H}$ & L & 11941 & 1593 \\
\hline 5 & 26 & 1.752 & $70 \cdot 8$ & L & $\mathbf{H}$ & L & $\mathbf{H}$ & 12619 & 2848 \\
\hline 6 & 23 & 1.751 & $63 \cdot 3$ & $\mathrm{~L}$ & $\mathbf{H}$ & L & $\mathbf{H}$ & 13310 & 3413 \\
\hline 7 & .20 & 1.812 & 76.9 & $\vec{H}$ & $\mathbf{L}$ & $\mathrm{L}$ & $\mathbf{H}$ & 16527 & 5440 \\
\hline 8 & 25 & 1.784 & $68 \cdot 4$ & $\mathbf{H}$ & $\overline{\mathrm{L}}$ & $\overline{\mathrm{L}}$ & $\mathbf{H}$ & 13126 & 3418 \\
\hline Mean & $22 \cdot 9$ & 1.785 & 69.7 & & & & & 13368 & \\
\hline SD & $2 \cdot 0$ & 0.06 & $4 \cdot 9$ & & & & & 1903 & \\
\hline
\end{tabular}

$\mathrm{H}$, high-exercise programme; L, low-exercise programme.

* Mean body-weight during study.

$\dagger$ From $7 \mathrm{~d}$ weighed food intake record.

Day

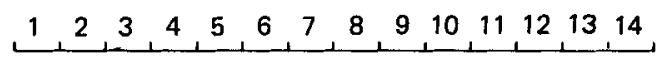

Diet

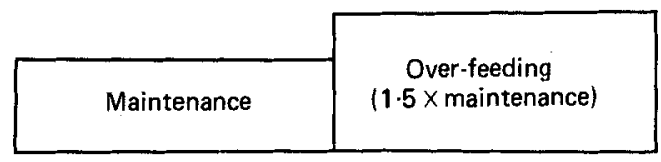

Faecal

collections

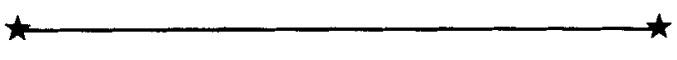

Urine

collections

Calorimetry
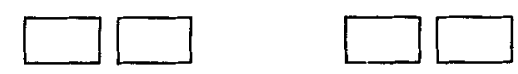

Fig. 1. Summary of experimental timetable.

\section{Experimental diets}

During the maintenance week each subject was given a level of energy intake which was close to that normally consumed by him in everyday life. This was determined before the study started by each subject measuring his food intake for $7 \mathrm{~d}$. The weighed inventory method, recently described by Bingham $e$ al. (1981) was used. Each subject's habitual energy intake and his energy intake during the study are presented in Tables 1 and 2 respectively. Two subjects (nos 3 and 7) were in fact given less than the amount recorded in their 
Table 2. Determination of metabolizable energy $(M E)$ intake $(k J / d)$ and comparison with $M E$ intake calculated from food tables (Paul \& Southgate, 1978)

\begin{tabular}{|c|c|c|c|c|c|c|}
\hline $\begin{array}{c}\text { Subject } \\
\text { no. }\end{array}$ & $\begin{array}{l}\text { Gross } \\
\text { energy } \\
\text { intake }\end{array}$ & $\begin{array}{l}\text { Energy } \\
\text { lost in } \\
\text { faeces }\end{array}$ & $\begin{array}{c}\text { Digestible } \\
\text { energy } \\
\text { intake }\end{array}$ & $\begin{array}{l}\text { Energy } \\
\text { lost in } \\
\text { urine }\end{array}$ & $\begin{array}{c}\mathrm{ME} \\
\text { intake }\end{array}$ & $\begin{array}{c}\text { Calculated } \\
\text { ME } \\
\text { intake }\end{array}$ \\
\hline \multicolumn{7}{|c|}{ Maintenance diet } \\
\hline 1 & 10417 & 577 & 9840 & 325 & 9515 & 10004 \\
\hline 2 & 13648 & 854 & 12794 & 457 & 12337 & 13037 \\
\hline 3 & 14725 & 769 & 13956 & 476 & 13480 & 14048 \\
\hline 4 & 12571 & 645 & 11926 & 396 & 11530 & 12026 \\
\hline 5 & 13648 & 838 & 12810 & 430 & 12380 & 13037 \\
\hline 6 & 13648 & 582 & 13066 & 388 & 12678 & 13037 \\
\hline 7 & 14725 & 617 & 14108 & 618 & 13490 & 14048 \\
\hline 8 & 13648 & 640 & 13008 & 401 & 12607 & 13037 \\
\hline Mean & 13379 & 690 & 12689 & 436 & 12252 & 12784 \\
\hline SD & 1380 & 113 & 1341 & 87 & 1275 & 1296 \\
\hline \multicolumn{7}{|c|}{ Over-feeding diet } \\
\hline 1 & 15763 & 703 & 15060 & 282 & 14778 & 15005 \\
\hline 2 & 20445 & 1154 & 19291 & 432 & 18859 & 19539 \\
\hline 3 & 22158 & 996 & 21162 & 358 & 20804 & 21050 \\
\hline 4 & 18813 & 948 & 17865 & 336 & 17529 & 18027 \\
\hline 5 & 20410 & 1056 & 19354 & 381 & 18973 & 19539 \\
\hline 6 & 20576 & 422 & 20154 & 248 & 19906 & 19539 \\
\hline 7 & 21951 & 653 & 21298 & 476 & 20822 & 21050 \\
\hline 8 & 20566 & 1073 & 19493 & 392 & 19101 & 19539 \\
\hline Mean & 20085 & 876 & 19210 & 363 & 18847 & 19161 \\
\hline SD & 2028 & 255 & 2007 & 75 & 1972 & 1937 \\
\hline
\end{tabular}

weighed-intake week as these values were considered to be unrealistically high (15463 and $16527 \mathrm{~kJ} / \mathrm{d}$ respectively), having been recorded during weeks of unusual physical activity.

With the use of food tables (Paul \& Southgate, 1978) a baseline diet was designed which provided $10 \mathrm{MJ} / \mathrm{d}$ and this was supplemented as required for each subject in units of $1 \mathrm{MJ} / \mathrm{d}$ in the form of special increments (sandwiches) which had the same composition as the diet as a whole and therefore could be added to the baseline diet without changing the over-all composition. The diets provided $13 \%$ of total energy from protein, $30 \%$ from fat and $57 \%$ from carbohydrate. Each day's intake was divided into three meals of equal size and identical composition. The meals were eaten at $09.00,13.30$ and 18.00 hours. All food had to be eaten.

The diets were made up of everyday well-accepted foods and were designed around a $2-d$ rotating menu to provide some variety. With the exception of a few items of fresh fruit and salad, the food for the entire study was purchased in bulk. All the food was prepared in the metabolic kitchen where it was weighed out to the nearest $1 \mathrm{~g}$. Standardized cooking and preparation techniques were used. Duplicate complete samples of each day's menu (baseline intake) were collected, homogenized and freeze-dried for analysis by bomb calorimetry.

During the over-feeding week the subject was given a fat supplement in addition to the maintenance diet. The calculated increase in energy intake was $50 \%$ and total fat intake rose from $30 \%$ of energy to $50 \%$ of energy. The $5 \mathrm{MJ}$ fat supplement was made up of $211 \mathrm{~g}$ double cream, $20 \mathrm{~g}$ maize oil and $112 \mathrm{~g}$ banana (the $6 \mathrm{MJ}$ supplement contained these amounts scaled up to $120 \%$ ). The ingredients were whipped together and frozen in three equal-sized portions which were eaten with the meals. All subjects tolerated the fat supplement well. Duplicates of a fat supplement given to each subject were taken for analysis. 


\section{Faecal collections}

Complete faecal collections were made throughout the study. For $3 \mathrm{~d}$ before the study started and on each day of the study, the subjects took thirty tiny radio-opaque markers (ten markers in a single gelatin capsule three times daily) as a non-absorbable faecal marker (Branch \& Cummings, 1978). The shape of the marker was changed at the beginning of the study and when the subject started over-feeding. At the end of the study the number and type of each marker in the stool was determined by $x$-ray. Stools containing only one type of marker were pooled for the two experimental periods. The number of markers in each pool was divided by 30 to give an estimate of how many day's faecal output the pool represented and from this the mean daily faecal weight was calculated. The pooled collections were freeze-dried and homogenized and gross energy on duplicate samples was determined with an adiabatic bomb calorimeter.

\section{Urine collections}

Complete $24 \mathrm{~h}$ urine collections were made throughout the study, from after rising in the morning until the same time the following day. Urine was collected into 2 -litre plastic bottles containing $50 \mathrm{ml} 1 \mathrm{M}$-hydrochloric acid as preservative. Urea-nitrogen was analysed using a Technicon Autoanalyzer N38 and total urine $\mathrm{N}$ was estimated assuming that urea-N accounts for $85 \%$ of total urinary N (Southgate \& Durnin, 1970).

\section{Body-weight}

The subject was weighed daily before breakfast, after having emptied his bladder and dressed in a cotton surgical gown. The scales used (CMS Weighing Equipment Ltd, London) were accurate to within $50 \mathrm{~g}$.

\section{Measurement of energy expenditure}

Apparatus. The indirect calorimeter used in the present experiment has already been described (Dallosso et al. 1982). The over-all calibration of the calorimeter has been checked by infusing a mixture of carbon dioxide- $\mathrm{N}_{2}(1: 4, \mathrm{v} / \mathrm{v})$ at a constant flow-rate measured with a wet gas meter. The measurements by the calorimeter agreed with those predicted from the infusion to better than $0.75 \%$. In an earlier experiment (Dallosso et al. 1982) the coefficient of variation of differences between fourteen duplicate $24 \mathrm{~h}$ measurements was as small as $1.03 \%$.

Procedure. The subject occupied the calorimeter on four separate occasions (see Fig. 1). These were from 20.00 hours on day 4 to 08.00 hours on day 6, from 20.00 hours on day 6 to 08.00 hours on day 8 , from 20.00 hours on day 11 to 08.00 hours on day 13 and from 20.00 hours on day 13 to 08.00 hours on day 15 . The temperature of the calorimeter was maintained at $26(\mathrm{SD} 0 \cdot 2)^{\circ}$ and the subject wore the same light-weight clothing for each run. There were two different programmes of activity that the subjects followed and these differed in the amount of exercise they contained. This was because one of the aims of the study was to look for an interaction between exercise and diet-induced thermogenesis (as reported in the following paper) and also in an attempt to explain the positive energy balance in the calorimeter that we had observed in a previous study (Dallosso et al. 1982). The values presented in the present paper apply to the period from 07.00 to 08.00 hours the following morning, i.e. neglecting the initial overnight period. On the high-exercise programme the subject cycled on a bicycle ergometer for $30 \mathrm{~min}$ on six occasions, with four sessions at $24.5 \mathrm{~W}$, one at $49 \mathrm{~W}$ and one at $98 \mathrm{~W}$. On the low-exercise programme the subject cycled for $30 \mathrm{~min}$ on two occasions at $24.5 \mathrm{~W}$ only. Three 30 min periods of standing were incorporated into the programme, i.e. at 22.30 to 23.00 hours before going to bed and at 07.30 to 08.00 hours on the first day when getting up in the morning. Meals were presented 
at $09.00,13.30$ and 18.00 hours and had to be eaten immediately and without delay. Outside the specified periods of activity the subject had to remain sitting and awake in the chair, but was free to read, write, telephone, listen to the radio or watch television. Between 07.00 and 08.00 hours on the second morning, a strictly-standardized measurement of the subject's BMR was made when the subject was woken by an intercom and instructed to lie awake but still on his back for $1 \mathrm{~h}$.

Analysis of results. Heat production values were obtained every $5 \mathrm{~min}$ of the day and night but for the purposes of analysis the mean of every 30 min was used. Total $24 \mathrm{~h}$ energy expenditure was calculated between 08.00 hours on the first morning in the calorimeter and 08.00 hours on the second morning in the calorimeter. The values were also looked at as night-time values (23.00-07.30 hours) and daytime values (07.30-23.00 hours) and the mean level of energy expenditure between 07.00 and 08.00 hours on the second morning was taken as the BMR.

\section{Statistical methods}

Analysis of variance was used to examine the energy expenditure results, separating out terms for subjects ( $7 \mathrm{df}$ ) and treatments ( $1 \mathrm{df}$ ). The two treatment effects were the Regimen effect (i.e. the maintenance diet $v$. over-feeding diet) and the Activity effect (i.e. high-activity programme $v$. low-activity programme). A number of interactions between these effects and the order in which the subjects performed the different programmes in the calorimeter were also looked at (see Table 6, p. 59). The treatment effects had $1 \mathrm{df}$, and therefore the $F$ ratios, with 1 and $17 \mathrm{df}$, were expressed as $t$ values, where the $t$ value is the square root of the $F$ ratio:

$$
t_{17 \mathrm{df}}=\sqrt{ } F_{(1,17 \mathrm{df})} .
$$

The analysis was done using the GENSTAT statistical language.

The rest of the values were analysed by Student's paired $t$ test. Means and standard deviations are presented.

\section{RESULTS}

\section{Experimental diets}

The gross energy contents of the diets were determined by adiabatic bomb calorimetry of freeze-dried duplicate samples taken at the beginning and end of the study and these values are presented in Table 2, together with the individually-determined values for the metabolizable energy intakes of the subjects. Although the two menus were designed to provide identical amounts of metabolizable energy, there were differences of $6-7 \%$ in the measured gross energy contents of the two menus and $2-4 \%$ differences in the duplicates taken at the beginning and end of the study. This is not surprising in view of the variability in the energy content of different foods. The design of the menus with appropriate storage of single batches of food to cover the whole study was aimed at minimizing the variability in food intake from day-to-day, but the observed variability is difficult to reduce when the diets used are based on foods rather than liquid formulas. There are several possible explanations to account for discrepancies between the anticipated values and those actually obtained; an important contributory factor is that the values in food tables are obtained from 'average' foods.

\section{Faecal excretion of energy}

The faecal values are included in Table 2 . With over-feeding, faecal weight $(\mathrm{g} / \mathrm{d})$ increased on average from 152 (SD 56.0) to 189 (SD 83.4) $(P<0.01)$. Faecal solids did not increase from the original value of $23.7 \%$ of the wet weight, but when expressed in absolute terms 
Table 3. Body-weight $(\mathrm{kg})$ of adult male subjects

(During days 1-7 the subjects ate a maintenance diet and during days 8-14 the subjects were over-fed.

The levels of energy intake and the composition of the two diets are given in Table 2 and on p. 51)

\begin{tabular}{cccc}
\hline $\begin{array}{c}\text { Subject } \\
\text { no. }\end{array}$ & Day 1 & Day 8 & Day 15 \\
\hline 1 & $64 \cdot 2$ & $63 \cdot 4$ & $64 \cdot 2$ \\
2 & $69 \cdot 3$ & $69 \cdot 0$ & $70 \cdot 4$ \\
3 & $74 \cdot 7$ & $75 \cdot 5$ & $77 \cdot 1$ \\
4 & $69 \cdot 5$ & $68 \cdot 5$ & $70 \cdot 2$ \\
5 & $71 \cdot 3$ & $70 \cdot 2$ & $71 \cdot 8$ \\
6 & $63 \cdot 4$ & $63 \cdot 5$ & $63 \cdot 9$ \\
7 & $76 \cdot 6$ & $77 \cdot 3$ & $77 \cdot 8$ \\
8 & 67.0 & $68 \cdot 1$ & $69 \cdot 7$ \\
Mean & $69 \cdot 5$ & $69 \cdot 4$ & $70 \cdot 6 *$ \\
sD & $4 \cdot 7$ & $5 \cdot 0$ & $5 \cdot 1$ \\
\hline
\end{tabular}

- Differences in mean body-weight on days 8 and 15 were statistically significant $(P<0.001)$.

average daily ouput (g) rose from 33.9 (SD 6.7) to $40 \cdot 3$ (SD 12.7). Faecal energy excretion was $5 \%$ of gross energy intake on the maintenance diet and $4.4 \%$ on the over-feeding diet. Therefore there was no evidence of malabsorption of energy on the over-feeding diet.

These values for faecal energy were included in the individual estimates of the metabolizable energy intakes. Table 2 shows that these observed measures are in general a little less than those estimated from the British food tables (Paul \& Southgate, 1978). This difference in theoretical and observed energy intakes of $2-5 \%$ is not explained by unusual faecal loss of energy because values of this order have been found previously by Southgate \& Durnin (1970), who confirmed the usefulness of Atwater factors with their inclusion of an allowance for faecal and urinary losses of energy. These Atwater values seem appropriate even in those subjects consuming a diet which, if given to provide $13 \mathrm{MJ}$ daily, contained approximately $32 \mathrm{~g}$ dietary fibre. The difference between observed and measured metabolizable energy does however indicate, as noted by Norgan \& Durnin (1980), the importance of documenting directly the energy content and digestibility of the diet during over-feeding experiments; in their study direct measurements of dietary energy also proved less than anticipated.

\section{Body-weight}

Table 3 summarizes the changes that occurred in body-weight during the maintenance week and over-feeding week. As a group there was no significant gain in body-weight during the maintenance week $(t 0 \cdot 22$, not significant) although two subjects did gain weight (subjects nos. 3 and 7). During the over-feeding week there was a significant increase in body-weight (kg) from 69.42 (SD 5.0) to 70.64 (SD 5.10) $(t 6.27, P<0.001$ ). All subjects gained weight and the weight gain ranged from $0.53 \mathrm{~kg}$ (subject no. 7) to $1.72 \mathrm{~kg}$ (subject no. 4).

\section{Energy expenditure in the calorimeter}

Complete sets of values were collected for all subjects. Figs. 2 and 3 show the patterns of $24 \mathrm{~h}$ heat production for the eight subjects on both activity programmes. Throughout the day and night the level of energy expenditure was higher on the over-feeding diet, although the differences were small. The difference was greatest in the afternoon and evening and decreased during the night until about 06.00 hours when it was scarcely present. 


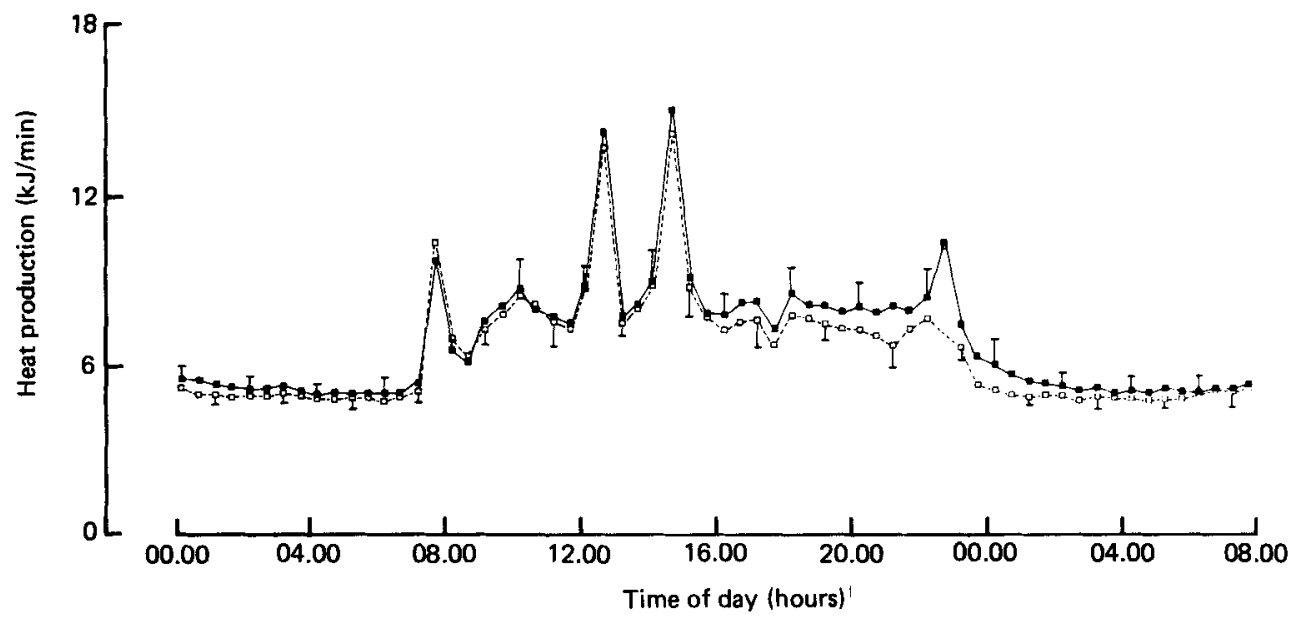

Fig. 2. Effect of fat over-feeding on pattern of $24 \mathrm{~h}$ energy expenditure while occupying the calorimeter on the low-activity programme. Group mean values and standard deviations, respresented by vertical bars $(n)$, of heat production $(\mathrm{kJ} / \mathrm{min})$ for every $30 \mathrm{~min}$ period on the maintenance diet $(\square)$ and the over-feeding diet (D) are shown. For details of treatments, see pp. 52-53 and Table 1.

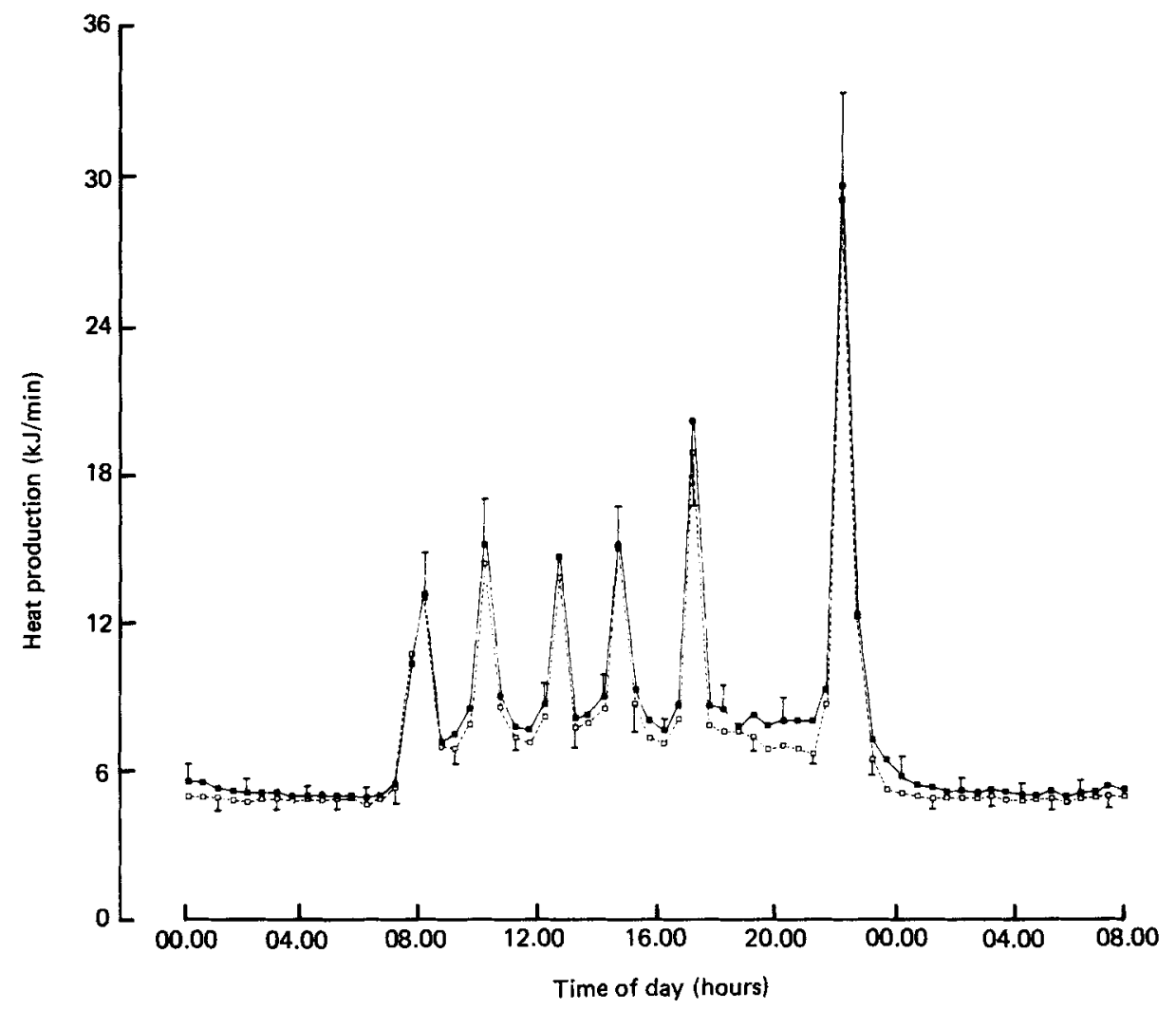

Fig. 3. Effect of fat over-feeding on pattern of $24 \mathrm{~h}$ energy expenditure while occupying the calorimeter on the high-activity programme. Group mean values and standard deviations, represented by vertical bars $(n 8)$, of heat production $(\mathrm{kJ} / \mathrm{min})$ for every $30 \mathrm{~min}$ period on the maintenance diet $(\square)$ and the over-feeding diet ( $\mathbf{\square}$ are shown. For details of treatments, see pp. 52-53 and Table 1. 
Table 4. Individual $24 h$ energy expenditure values $(k J / d)$ in the calorimeter for adult men while following two different exercise programmes on two different levels of energy intake. $24 \mathrm{~h}$ was the period from 08.00 hours on day 2 to 08.00 hours on day 3 in the calorimeter

\begin{tabular}{|c|c|c|c|c|}
\hline \multirow{2}{*}{$\begin{array}{l}\text { Energy intake*... } \\
\text { Exercise programme*... } \\
\quad \text { Subject no. }\end{array}$} & \multicolumn{2}{|c|}{ Maintenance } & \multicolumn{2}{|c|}{ Over-feeding } \\
\hline & Low & High & Low & High \\
\hline 1 & 9261 & 10366 & 9469 & 10866 \\
\hline 2 & 10710 & 11821 & 11206 & 12475 \\
\hline 3 & 10284 & 11657 & 11181 & 12658 \\
\hline 4 & 9494 & 11222 & 10308 & 11432 \\
\hline 5 & 10132 & 11581 & 10499 & 12241 \\
\hline 6 & 9425 & 10947 & 9733 & 12057 \\
\hline 7 & 11236 & 13274 & 11907 & 14163 \\
\hline 8 & 8986 & 10547 & 9856 & 11408 \\
\hline Mean & 9941 & 11427 & 10520 & 12163 \\
\hline SD & 780 & 911 & 849 & 1010 \\
\hline
\end{tabular}

* For details, see pp. 52-53 and Table 1.

Table 4 gives the individual values of $24 \mathrm{~h}$ heat production in the calorimeter from 08.00 to 08.00 hours, and the values for different times of the day and night as well as the BMR are presented in Table 5. Table 6 summarizes the results of the analyses of variance performed on the various sets of energy expenditure values.

It was predictable that the most significant treatment effects were those of increasing the amount of exercise on energy expenditure (the 'activity' effect). This was present in the $24 \mathrm{~h}$ values $(t 22.68, P<0.001)$ and the daytime values $(t 21.93, P<0.001)$. The mean absolute increases in $24 \mathrm{~h}$ energy expenditure (kJ) were 1486 (SD 309) on the maintenance diet (a $15 \%$ increase) and 1643 (SD 440) on the over-feeding diet (a 16\% increase).

The effect of over-feeding (the 'regimen' effect) was to increase $24 \mathrm{~h}$ energy expenditure $(t 9.53, P<0.01$ ) by $5.6 \%$ on the low-activity day and by $6.4 \%$ on the high-activity day. The subjects exhibited a wide range of response to over-feeding on both the activity programmes $(2-10 \%)$. When the increase in $24 \mathrm{~h}$ energy expenditure during over-feeding was expressed as a percentage of the extra energy ingested, $9 \%$ of the extra energy was accounted for by increased expenditure on the inactive day and $11 \%$ on the high-exercise regimen. The over-feeding effect was seen during the daytime $(t 5.94, P<0.001)$ and the night $(t 12.26, P<0.001)$ and during the BMR period $(t 4.41, P<0.001)$ which was measured $13 \mathrm{~h}$ after the last meal.

The analyses of variance brought to light a number of significant interaction effects between the factors being studied and the order in which subjects completed their runs in the calorimeter. For example, in the night-time and BMR values there were significant interactions between the response to over-feeding and the order in which the subjects performed the exercise conditions on the maintenance diet $(t 4.42, P<0.001$ and $t 2.14$, $P<0.05$ ). In the $24 \mathrm{~h}$ and daytime values the effect of the extra exercise depended on the order in which the subjects performed the activity programmes $(t 3.5, P<0.002$ and $t 2.95$, $P<0.005)$. It is not easy to say which of the statistically-significant interaction effects have real physiological implications. The order of presentation of the different exercise programmes was randomized for different subjects but all subjects ate the maintenance diet first followed by the over-feeding diet. Therefore it is possible that some of the interaction effects could be due to progressive changes as the over-feeding continued. 


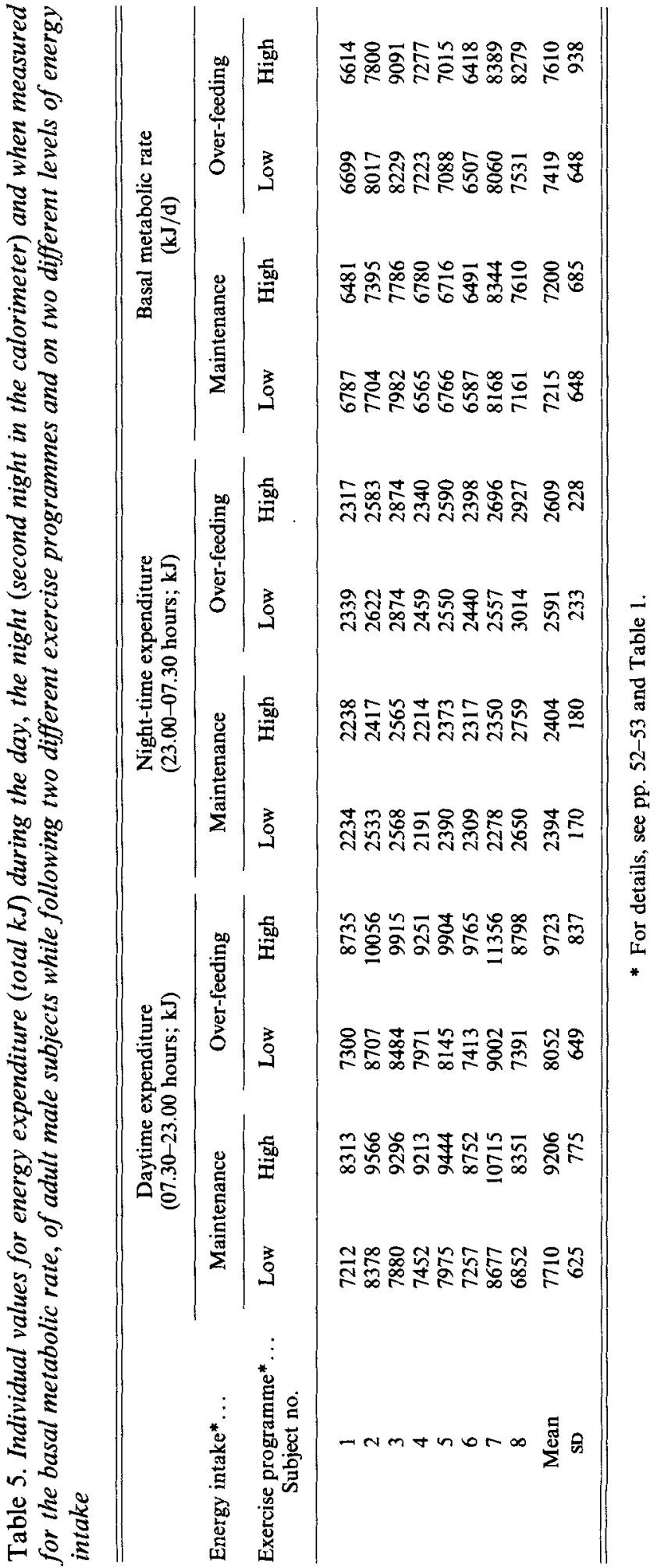


Table 6. Energy expenditure in relation to the feeding regimen, activity and order of study in individual subjects: a summary of an analysis of variance with t values

\begin{tabular}{|c|c|c|c|c|}
\hline \multirow[b]{2}{*}{ Source of variation } & \multicolumn{3}{|c|}{ Energy expenditure } & \multirow[b]{2}{*}{$\begin{array}{c}\text { Basal metabolic rate } \\
07.30-08.00 \\
\text { hours) }\end{array}$} \\
\hline & $\begin{array}{c}24 \mathrm{~h} \\
(08.00-08.00 \\
\text { hours })\end{array}$ & $\begin{array}{c}\text { Daytime } \\
\text { (07.30-23.00 } \\
\text { hours })\end{array}$ & $\begin{array}{l}\text { Night-time } \\
(23.00-08.00 \\
\text { hours })\end{array}$ & \\
\hline Regimen effect & $9 \cdot 53^{* * *}$ & $5.94^{* * *}$ & $12 \cdot 26^{* * *}$ & $4 \cdot 41^{* * *}$ \\
\hline Activity effect & $22 \cdot 68^{* * *}$ & $21 \cdot 93^{* * *}$ & $0 \cdot 27$ & 1.24 \\
\hline Regimen $\times$ subject interaction $A$ & 0.87 & 0.56 & $1 \cdot 21$ & 1.77 \\
\hline Regimen $\times$ subject interaction $B$ & 1.73 & 0.52 & $4 \cdot 42^{* * *}$ & $2 \cdot 14^{*}$ \\
\hline Regimen $\times$ activity interaction & $1 \cdot 14$ & $1 \cdot 21$ & 0.88 & 1.44 \\
\hline Activity $\times$ subject interaction $A$ & $3 \cdot 50+1 \dagger$ & $2.95^{* *}$ & 1.81 & $1 \cdot 20$ \\
\hline Activity $\times$ subject interaction B & 1.08 & $0 \cdot 90$ & $1 \cdot 14$ & $3 \cdot 38+\dagger \dagger$ \\
\hline
\end{tabular}

Interaction A compares those subjects who did the high-activity programme first on the over-feeding diet with those who did the low-activity programme first on the over-feeding diet (see Table 1).

Interaction B compares those subjects who did the low-activity programme first on the maintenance diet with those who did the high-activity programme first on the maintenance diet (see Table 1).

$* P<0.05, * * P<0.01$, $+\dagger+P<0.005, * * * P<0.001$.

Another possible explanation is that the subjects in the groups with heavy exercise first were different from those who initially undertook light activity. The subjects chosen to have the low-activity day first on the maintenance diet were by chance significantly shorter $(t 3.86$, $P<0.01)$ and ligher $(t 3.91, P<0.01)$ and had a greater percentage body fat $(t 3.91$, $P<0.01)$.

\section{DISCUSSION}

The analysis of a complete (i.e. marker checked) collection of faeces excluded the possibility of fat malabsorption as an important factor in the preservation of energy balance. With over-feeding, there was a significant increase in daily faecal energy excretion, but when expressed as a proportion of the gross energy intake, the faecal energy losses were similar on the maintenance diet $(5 \%)$ and the over-feeding diet $(4 \%)$ and were close to those found by Rai et al. (1975) and Norgan \& Durnin (1980). These results therefore do not support the hypothesis of MacNair (1979) that individuals who are able to maintain their body-weight do so by 'limited absorption rather than enhanced utilization of nutrients'.

Fat over-feeding in animals can be an effective way of inducing obesity and it is generally included in the list of animal models of experimental obesity (Bray \& York, 1979; Miller, 1979). Studies with rodents (Tepperman et al. 1978; Lin et al. 1979) have shown that a high-fat diet is utilized more efficiently than a high-carbohydrate diet and therefore leads to an increase in body fat. This increased susceptibility to weight gain with a high-fat diet appears to be age and species related (Schemmel et al. 1970) and to depend on the type of fat given (Bourgeois et al. 1983). Therefore results from animal work would lead us to anticipate substantial weight gain since the present subjects were being over-fed on a diet with a high fat content.

The present subjects were over-fed with an amount of fat designed to be physiologically relevant. The maintenance diet of $30 \%$ of energy from fat is equivalent to that recommended by some organizations as nutritionally appropriate (US Senate Committee on Nutrition and Human Needs, 1977). The subjects' average pre-study fat intakes ranged from 29 to $49 \%$, a slightly smaller range than the $27-54 \%$ span found in sixty-three adults living near 
Cambridge (Bingham et al. 1981). The two levels of fat feeding in the present study were therefore within the compass of those observed in the community.

With any over-feeding there is bound to be some degree of increase in metabolic rate due to the obligatory thermogenic cost of metabolizing and storing the extra food as fat. It is necessary to discriminate between this obligatory increase in metabolic rate and any adaptive thermogenic response to over-feeding (described by some as luxuskonsumption). Flatt (1978) calculated the theoretical energy cost of fat storage in adipose tissue to be $3 \%$ of the energy stored when the substrate is fat, compared with the much greater cost of $19 \%$ when the substrate is carbohydrate. This latter value represents the high energy cost of de novo lipogenesis. In the present study the subjects were given a supplement made up almost entirely of fat, in excess of the mixed diet designed to maintain body-weight. If the assumption is made that the fat supplement has been used specifically for depositing fat in adipose tissue, while the baseline diet of mixed composition was reserved for the body's maintenance requirements, then the minimum obligatory increase in metabolic rate should be close to $3 \%$ as calculated by Flatt (1978). However, it may be 'unwarranted to assume that ... energy derived from a particular ration component [is used for maintenance] and another component for the deposition of fat' (Blaxter, 1969). Nevertheless, calorimetric calculations of each individual's response to the selective fat over-feeding may allow this cautionary note to be set aside.

\section{Calculating nutrient storage}

Each individual's $N$ excretion on the diet was estimated for the $24 \mathrm{~h}$ periods in the calorimeter by subtracting an average daily value for faecal $N$ loss (Isaksson, 1980), together with the urinary $N$ output estimated from the urea- $N$ excretion during the $24 \mathrm{~h}$ in the calorimeter from the calculated dietary $\mathrm{N}$ intake. No allowance was made for skin $\mathrm{N}$ losses. The specific $\mathrm{N}$ input on the calorimeter day was assumed to be equivalent to that during the course of the experimental period.

The individual's average $24 \mathrm{~h} \mathrm{O}_{2}$ uptake, respiratory quotient and urine- $\mathrm{N}$ excretion were used to calculate the rate of carbohydrate and fat oxidation while in the chamber (Consolazio et al. 1963). By comparing this with intake the net storage of carbohydrate and fat could be calculated for each individual (Table 7).

During the maintenance period all but one of the subjects remained in positive energy balance within the chamber even on the high-activity regimen (Table 7). Fat intake approximated to fat oxidation, there being on average a $14 \mathrm{~g}$ positive balance on low activity and a $14 \mathrm{~g}$ negative balance during high activity. Carbohydrate intake was in excess of calculated glucose oxidation. How much carbohydrate was stored as muscle or liver glycogen or by fat synthesis during the relatively inactive time spent in the chamber is impossible to discern from these calculations. Nor can one exclude the possibility that some of the dietary fat was deposited preferentially with fat oxidation coming from carbohydratederived substrate. The net balance is calculable but alternative metabolic pathways are recognized to have very different energetic effects.

By comparing within each individual the change in net balance of substrate induced entirely by fat over-feeding (Table 8 ) it is evident that about $0.51 \mathrm{mg} \mathrm{N} / \mathrm{kJ}$ was stored compared with values of $0.36 \mathrm{mg} \mathrm{N} / \mathrm{kJ}$ observed by Elwyn (1980) in post-operative or depleted patients. With fat over-feeding there appeared to be no sparing of carbohydrate and on the high-exercise regimen there may have been a small increase in carbohydrate utilization. These calculations therefore suggest that one can consider the additional dietary fat to be stored as triglyceride, there being no increase in carbohydrate storage on fat over-feeding. If dietary fat storage is assumed to involve a maximum of $3 \%$ of the additional fat energy ingested (Flatt, 1978), assuming that ketone body production is not a normal 
Table 7. Daily balances (i.e. storage) between intake and expenditure of energy and between intake and oxidation of nitrogen, carbohydrate and fat are presented for each individual on the $4 d$ in the calorimeter

\begin{tabular}{|c|c|c|c|c|c|c|c|c|}
\hline \multirow{2}{*}{$\begin{array}{l}\text { Exercise } \\
\text { programme*.. }\end{array}$} & \multicolumn{2}{|c|}{$\begin{array}{l}\text { Energy storage } \\
(\mathrm{kJ} / \mathrm{d})\end{array}$} & \multicolumn{2}{|c|}{$\begin{array}{c}\text { Nitrogen storage } \\
\qquad(\mathrm{g} / \mathrm{d})\end{array}$} & \multicolumn{2}{|c|}{$\begin{array}{l}\text { Carbohydrate } \\
\text { storage }(g / d)\end{array}$} & \multicolumn{2}{|c|}{$\begin{array}{l}\text { Fat storage } \\
(\mathrm{g} / \mathrm{d})\end{array}$} \\
\hline & Low & High & Low & High & Low & High & Low & High \\
\hline \multicolumn{9}{|c|}{ Maintenance diet } \\
\hline $\begin{array}{c}\text { Subject no. } \\
1 \\
2 \\
3 \\
4 \\
5 \\
6 \\
7 \\
8\end{array}$ & $\begin{array}{r}845 \\
2489 \\
3935 \\
2662 \\
2983 \\
3778 \\
3128 \\
4200\end{array}$ & $\begin{array}{r}-159 \\
1468 \\
2563 \\
926 \\
2171 \\
2284 \\
1048 \\
2652 \\
\end{array}$ & $\begin{array}{r}0.61 \\
0.69 \\
1.02 \\
1.55 \\
1.81 \\
3.02 \\
-2.21 \\
2.98\end{array}$ & $\begin{array}{l}1.39 \\
0 \\
0.02 \\
2.18 \\
2.98 \\
2.38 \\
-2.90 \\
2.69\end{array}$ & $\begin{array}{l}123 \\
216 \\
224 \\
158 \\
215 \\
180 \\
154 \\
164\end{array}$ & $\begin{array}{r}96 \\
189 \\
201 \\
163 \\
150 \\
118 \\
177 \\
201\end{array}$ & $\begin{array}{r}-19.1 \\
-13.7 \\
+21.5 \\
+12.3 \\
-3.6 \\
+28.6 \\
+40.2 \\
+47.1\end{array}$ & $\begin{array}{r}-35.4 \\
-26.4 \\
-6.9 \\
-36.4 \\
+1.1 \\
+19.5 \\
-21.3 \\
-8.4\end{array}$ \\
\hline $\begin{array}{l}\text { Mean } \\
\text { SD }\end{array}$ & $\begin{array}{l}3003 \\
1066\end{array}$ & $\begin{array}{r}1619 \\
978\end{array}$ & $\begin{array}{l}1.18 \\
1.66\end{array}$ & $\begin{array}{l}1.09 \\
1.98\end{array}$ & $\begin{array}{r}179 \\
36\end{array}$ & $\begin{array}{r}162 \\
39\end{array}$ & $\begin{array}{r}+14 \cdot 2 \\
24 \cdot 6\end{array}$ & $\begin{array}{r}-14.3 \\
19.3\end{array}$ \\
\hline \multicolumn{9}{|c|}{ Fat over-feeding } \\
\hline 1 & 5608 & 4202 & $2 \cdot 46$ & 3.15 & 115 & 43 & 109 & 102 \\
\hline 2 & 8569 & 7292 & 1.81 & $2 \cdot 48$ & 207 & 179 & 153 & 130 \\
\hline 3 & 9954 & 8611 & 4.62 & 3.79 & 180 & 147 & 193 & 176 \\
\hline 4 & 7885 & 6617 & 3.63 & $4 \cdot 16$ & 129 & 113 & 161 & 135 \\
\hline 5 & 9087 & 7351 & 4.88 & 5.36 & 192 & 102 & 164 & 158 \\
\hline 6 & 9916 & 7644 & 9.46 & 9.81 & 228 & 152 & 157 & 131 \\
\hline 7 & 9435 & 7540 & 0.32 & 0.90 & 206 & 127 & 180 & 165 \\
\hline 8 & 9866 & 8359 & $4 \cdot 48$ & 3.07 & 181 & 65 & 190 & 207 \\
\hline Mean & 8790 & 7202 & 3.96 & 4.09 & 180 & 116 & 163 & 151 \\
\hline SD & 1477 & 1363 & 2.73 & 2.65 & 39 & 45 & 27 & 33 \\
\hline
\end{tabular}

- For details. see p. 53.

intermediate step in oxidation and that the additional fat stored is not itself being constantly recycled, it then seems reasonable to conclude that thermogenesis in excess of this value is regulatory rather than obligatory.

\section{The magnitude of regulatory thermogenesis}

The mean increase in $24 \mathrm{~h}$ energy expenditure on over-feeding when expressed as a percentage of the excess energy given amounted to 11 and $9 \%$ on high- and low-activity regimens, i.e. a similar order of magnitude to the $13 \%$ reported by Dauncey $(1980)$ and $14 \%$ by Apfelbaum et al. (1971). Therefore luxuskonsumption in the three groups is small when studied by whole-body calorimetry and amounts to regulatory thermogenesis of only 6-11\% of the excess energy ingested. A similar study on lean women (Zed \& James, 1982) found a mean thermogenic response to fat over-feeding of $13 \%$ of the excess energy ingested, while the equivalent response in a group of obese women was only $5 \%$. Other over-feeding studies have been restricted to measuring changes in BMR or RMR and sometimes the energy costs of a few activities.

If the average increase of energy expenditure seen in the present study is compared with Norgan \& Durnin's (1980) values, it is evident that the increase in BMR on fat over-feeding occurs much earlier than at 6 weeks, but the early increase in BMR is less $(2.8$ and $5.7 \%$ in the low-and high-activity days during over-feeding) than the $12 \%$ rise after 6 weeks found 
Table 8. Individual daily differences in the storage of energy, nitrogen, carbohydrate and fat as a result of fat over-feeding are presented for the two activity programmes

\begin{tabular}{|c|c|c|c|c|}
\hline \multirow[b]{2}{*}{ Subject no. } & \multirow{2}{*}{$\begin{array}{l}\text { Increase in } \\
\text { energy stored } \\
(\mathrm{kJ} / \mathrm{d})\end{array}$} & \multicolumn{3}{|c|}{ Change in daily nutrient stored $(\mathrm{g} / \mathrm{d})$} \\
\hline & & Nitrogen & Carbohydrate & Fat \\
\hline \multicolumn{5}{|c|}{ Low-activity programme* } \\
\hline 1 & 4763 & 1.85 & -8 & 128 \\
\hline 2 & 6080 & $1 \cdot 12$ & -9 & 167 \\
\hline 3 & 6019 & 3.60 & -44 & 172 \\
\hline 4 & 5223 & $2 \cdot 08$ & -29 & 149 \\
\hline 5 & 6104 & 3.07 & -23 & 168 \\
\hline 6 & 6138 & 6.44 & +48 & 128 \\
\hline 7 & 6307 & $2 \cdot 53$ & +52 & 140 \\
\hline 8 & 5666 & $1 \cdot 50$ & +17 & 143 \\
\hline Mean & 5788 & $2 \cdot 77$ & 0.5 & 149 \\
\hline SD & 537 & 1.69 & $35 \cdot 3$ & 18 \\
\hline \multicolumn{5}{|c|}{ High-activity programme* } \\
\hline 1 & 4361 & 1.76 & -53 & 137 \\
\hline 2 & 5824 & 2.48 & -10 & 156 \\
\hline 3 & 6048 & 3.77 & -54 & 183 \\
\hline 4 & 5691 & 1.98 & -50 & 171 \\
\hline 5 & 5180 & $2 \cdot 38$ & -48 & 157 \\
\hline 6 & 5360 & $7 \cdot 43$ & +34 & 111 \\
\hline 7 & 6492 & 3.80 & -50 & 186 \\
\hline 8 & 5707 & $0 \cdot 38$ & -136 & 215 \\
\hline Mean & 5583 & 2.99 & -46 & 165 \\
\hline SD & 636 & $2 \cdot 10$ & 48 & 32 \\
\hline
\end{tabular}

For details, see p. 53.

by Norgan \& Durnin (1980). Similarly, total $24 \mathrm{~h}$ energy expenditure increased by $6 \%$ in our study compared with a value of $10 \%$ in Norgan \& Durnin's (1980) study. The present values do not suggest that Norgan \& Durnin (1980) missed an important component of energy expenditure unless, as recently suggested by Passmore (1982), the key to the preservation of energy balance is a change in the spontaneous level of physical activity; this is difficult to document. Even so, as noted by Garrow (1974), such explanations do not readily account for the purported ability of individuals to maintain body-weight despite sustained changes in energy intake.

\section{Individual variability}

Although the mean response to over-feeding was not very substantial, not all subjects responded to the same extent. The increase in $24 \mathrm{~h}$ energy expenditure ranged from 3.5 to $17.4 \%$ of the extra energy fed, while the equivalent range for the study of Dauncey (1980) is even wider ( -1 to $25 \%$ ). Thus it appears that some subjects were able to respond much more than others, although none of them even approached the level of expenditure needed for complete compensation. One explanation is that different individuals have different abilities for dissipating heat. A significant negative relationship between percentage body fat and the response to over-feeding (Fig. 4) was observed if Dauncey's (1980) values are included with the present study. This does not, however, mean that the relationship is primary. Subjects with the larger adipose tissue mass may sequester excess fat more readily and thereby not stimulate thermogenesis. A marked thermogenic response to feeding was demonstrated in a patient with lipodystrophy, where fat deposition in adipose tissue was 


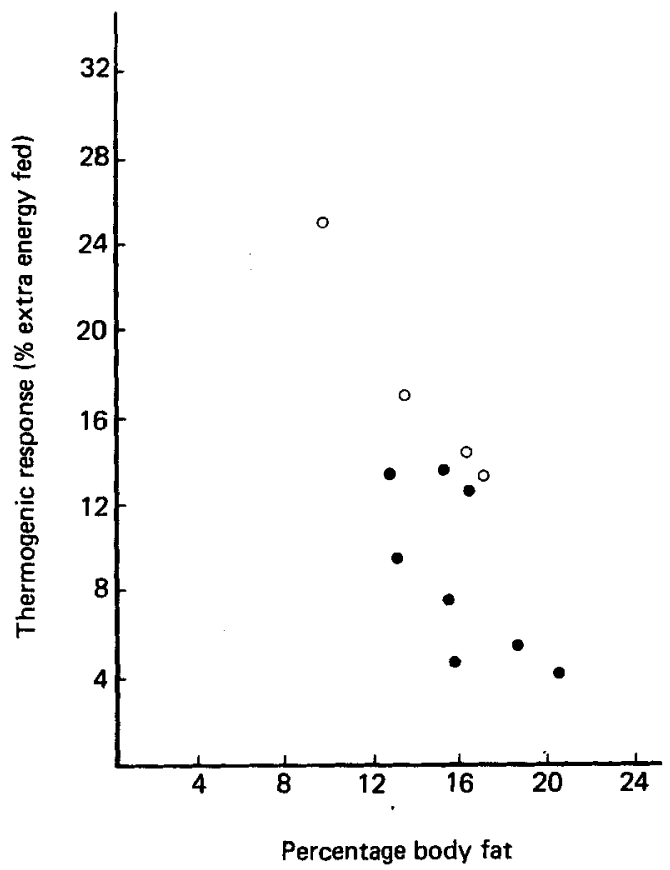

Fig. 4. Relationship between the thermogenic response to over-feeding on a diet rich in fat and the body fat content of the individual $(r 0.76, P<0.01)$. The percentage body fat calculated from the sum of skinfolds (Durnin \& Womersley, 1974) and the thermogenic response to over-feeding (increase in $24 \mathrm{~h}$ energy expenditure as a percentage of the extra energy fed) are shown for the present subjects $(O)$ and the male subjects of Dauncey (1980) (O).

not possible (Robbins et al. 1979). Thus, in theory, the development of excess adipose tissue may be perpetuated by progressive impairment of thermogenesis on fat feeding.

In conclusion, the present results have demonstrated in the group as a whole only a small thermogenic component in excess of that anticipated for the energy costs of fat deposition. Those individuals with the greatest thermogenesis were the thinner members of the group, but this thermogenic response may not be constitutional and in any case amounted at most to $17 \%$ of the energy ingested. More prolonged studies with high-carbohydrate diets or mixed over-feeding and body compositional measurements are needed to assess whether other nutrients are more effective in stimulating thermogenesis to an extent sufficient for thermogenesis to act as a major mechanism for maintaining energy balance in man.

The authors are grateful to Mr T. J. Cole, Miss H. L. Davies and Mr P. R. Murgatroyd for their help during the study. H.M.D. gratefully acknowledges the receipt of a Research Studentship from the Medical Research Council.

\section{REFER ENCES}

Adam, J. M., Best, T. W. \& Edholm, O. G. (1961). Journal of Physiology (London) 156, 38P.

Apfelbaum, M., Borstarron, J. \& Lacatis, D. (1971). American Journal of Clinical Nutrition 24, 1408-1409.

Bingham, S., McNeil, N. I. \& Cummings, J. H. (1981). British Journal of Nutrition 45, 23-34.

Blaxter, K. L. (1969). The Energy Metabolism of Ruminants, 3rd ed. London: Hutchinson \& Co. Ltd.

Bourgeois, F., Alexin, A. \& Lemonnier, D. (1983). British Journal of Nutrition 49, 17-26.

Branch, W. J. \& Cummings, J. H. (1978). Gut 19, 371-376.

Bray, G. A. \& York, D. A. (1979). Physiological Reviews 59, 719-784. 
Consolazio, C. F., Johnson, R. E. \& Pecora, L. J. (1963). Physiological Measurements of Metabolic Functions in Man. London: McGraw-Hill.

Dallosso, H. M. \& James, W. P. T. (1984). British Journal of Nutrition 52, 65-72.

Dallosso, H. M., Murgatroyd, P. R. \& James, W. P. T. (1982). Human Nutrition: Clinical Nutrition 36C, $25-39$.

Danforth, E., Horton, E. S., O'Connell, M., Sims, E. A. H., Burger, A. G., Ingbar, S. H., Braverman, L. \& Vagenakis, A. G. (1979). Journal of Clinical Investigation 64, 1336-1347.

Dauncey, M. J. (1980). British Journal of Nutrition 43, 257-269.

Durnin, J. V. G. A. \& Womersley, J. (1974). British Journal of Nutrition 32, 77-97.

Elwyn, D. H. (1980). Critical Care Medicine 8 (1), 9-20.

Flatt, J. P. (1978). In Recent Advances in Obesity, vol. 2, pp. 211-228 [G. A. Bray, editor]. London: Newman Publishing.

Garrow, J. S. (1974). Energy Balance and Obesity in Man. Amsterdam: Elsevier.

Isaksson, B. (1980). American Journal of Clinical Nutrition, 33, 4-5.

Lin, P., Romsos, D. R., Vander Tuig, J. G. \& Leveille, G. A. (1979). Journal of Nutrition 109, 1143-1153.

MacNair, A. L. (1979). Lancet ii, 1300.

Metropolitan Life Insurance Co. (1960). Statistical Bulletin no. 41.

Miller, D. S. (1979). In Animal Models of Obesity, pp. 131-141 [M. Festing, editor]. London: Macmillan Press Ltd.

Miller, D. S. \& Mumford, P. (1967). American Journal of Clinical Nutrition 20, 1212-1222.

Miller, D. S., Mumford, P. \& Stock, M. J. (1967). American Journal of Clinical Nutrition 20, $1223-1229$.

Neumann, R. O. (1902). Archives of Hygiene 45, 1-87.

Norgan, N. G. \& Durnin, J. V. G. A. (1980). American Journal of Clinical Nutrition 33, 978-988.

Passmore, R. (1982). Proceedings of the Nutrition Society 41, 161-165.

Paul, A. A. \& Southgate, D. A. T. (1978). McCance and Widdowson's The Composition of Foods, 4th ed. London: H. M. Stationery Office.

Rai, R. M., Malhotra, M. S., Dimri, G. P. \& Sampathkumar, T. (1975). American Journal of Clinical Nutrition 28, 242-245.

Robbins, D. C., Danforth, E., Horton, E. S., Burse, R. L., Goldman, R. F. \& Sims, E. A. H. (1979). Metabolism 28, 908-916.

Schemmel, R., Mickelson, O. \& Gill, J. L. (1970). Journal of Nutrition 100, 1041-1048.

Sims, E. A. H., Danforth, E., Horton, E. S., Bray, G. A., Glennon, J. A. \& Salans, L. B. (1973). Recent Progress in Hormone Research 29, 457-496.

Southgate, D. A. T. \& Durnin, J. V. G. A. (1970). British Journal of Nutrition 24, 517-535.

Tepperman, H. M., De Witt, J. \& Tepperman, J. (1978). Journal of Nutrition 108, 1924-1931.

US Senate Committee on Nutrition and Human Needs (1977). Dietary Goals for the United States. Washington, DC: US Government Printing Office.

Zed, C. A. \& James, W. P. T. (1982). Proceedings of the Nutrition Society 41, 32A. 